\title{
Density, abundance and extractive potential of the mangrove crab, Ucides cordatus (Linnaeus, 1763) (Brachyura, Ocypodidae): subsidies for fishery management
}

\author{
MARCELO A.A. PINHEIRO ${ }^{1, * *}$, MARCELO R. SOUZA ${ }^{2, *}$, \\ LUCIANA C.M. SANTOS ${ }^{3, *}$ and ROBERTO F.C. FONTES \\ ${ }^{1}$ Universidade Estadual Paulista/UNESP, Instituto de Biociências/IB, Campus do Litoral Paulista/ \\ CLP, Laboratório de Biologia da Conservação de Crustáceos e Ambientes Costeiros, Praça \\ Infante Dom Henrique, s/n, Parque Bitaru, 11330-900 São Vicente, SP, Brazil \\ ${ }^{2}$ Instituto de Pesca/APTA/SAA/SP, Avenida Bartolomeu de Gusmão, 192, Ponta da Praia, 11030-906 Santos, SP, Brazil \\ ${ }^{3}$ Instituto Federal de São Paulo/IFSP, Campus Pirituba, Avenida Mutinga, \\ 951, Jardim Santo Elias, 05110-000 São Paulo, SP, Brazil
}

Manuscript received on February 4, 2017; accepted for publication on October 4, 2017

\begin{abstract}
Ucides cordatus is a relevant fishery resource of Brazilian mangroves and requires legal normative to sustainable use based on stock assessment and management. This study evaluated some population parameters (structure, density, abundance, fishery potential and stock) of this crab species in Brazil Southeast (São Paulo, State), discussing the use of the results to delineate fishery management strategies. Density was monthly evaluated (September 1998 to August 1999), using five sample quadrats of 2x2 m. Density (ind. $\mathrm{m}^{-2}$ ) was indirectly estimated by counting the opened (with biogenic activity) and closed galleries, and contrasted with flooding level by tides using the vertical distribution of macroalgae in the base of trees. Density of $U$. cordatus ranges from 2 to 11 ind. $\mathrm{m}^{-2}\left(6 \pm 2\right.$ ind. $\left.\mathrm{m}^{-2}\right)$ and statistical difference occurred among monthly means $(\mathrm{F}=11.58 ; p=0.000)$. The relationship density vs. tidal flooding indicated a decrease of $U$. cordatus density in mangroves with higher levels of tidal flooding $(\mathrm{r}=-0.94 ; p=0.001)$. The total abundance of $U$. cordatus was estimated in 63.7 millions of crabs in $10.61 \mathrm{~km}^{2}$, with a reduction of $34.9 \%$ due to total mortality discount. Estimates like that are uncommon in literature, and could be used for fishery forecasts, allowing improvement by the introduction of new variables to be known in the future.
\end{abstract}

Key words: crab, crustacean, fishery, management, mangrove, population.

\section{INTRODUCTION}

Ucides cordatus (Linnaeus, 1763) is a semi terrestrial crab endemic of mangrove forests, and distributed along the tropical and sub-tropical

Correspondence to: Marcelo Antonio Amaro Pinheiro

E-mail: pinheiro@clp.unesp.br

*Grupo de Pesquisa em Biologia de Crustáceos/CRUSTA mangroves of the eastern Americas from southern Florida to southern Brazil (Bright and Hogue 1972, Melo 1996), where it is popularly called 'uçá'crab. In mangrove ecosystem this crab develops a major ecological function, consuming 81 to $98 \%$ of leaf litter available on mangrove sediments (Koch 1999, Nordhaus et al. 2006). According to 
Wolff et al. (2000), 75\% of the Brazilian mangrove biomass is composed by macrofaunal organisms, as $U$. cordatus (84\%) and Uca spp. (16\%), preventing an exportation of leafs/propagules with ebb tides to adjacent coastal areas. These vegetal items are converted in particulate organic matter (Nordhaus and Wolff 2007) and, then incorporated in mangrove sediments by these crabs when they dig their galleries (bioturbation) (Kristensen 2008). Therefore, leaf recycling by U. cordatus is the principal retention factor of carbon and nutrients in mangroves, and responsible by the high productivity of this ecosystem (Jennerjahn 2012, Koch and Wolff 2002, Nordhaus et al. 2006).

Due to the expressive size in adult phase, the 'uçá'-crab is used as human food and it is very commercially explored in many Brazilian regions, mainly in North and Northeast (Blandtt and Glaser 2000, Diele et al. 2005, Ibama 1994, Monteiro and Coelho-Filho 2004, Santos et al. 2016). Wolff et al. (2000) mentioned this crab species as a principal fishery resource in some mangroves of Brazilian North, with an annual capture estimated in 1,500 tons, in an area of $100 \mathrm{~km}^{2}$. Due to the intense exploration of $U$. cordatus in Brazil its mean size and weight have annually decreased in some Brazilian mangroves (Alves and Nishida 2004, Amaral and Jablonski 2005), as a result of their reduced growth (Pinheiro et al. 2005), use of non selective traps to capture this crustacean (Fiscarelli and Pinheiro 2002, Nordi et al. 2009, Pinheiro and Fiscarelli 2001), no compliment of the closed fishing law (Rodrigues et al. 2000), and an increase of mortality due to improper transport (Legat et al. 2006).

Brazilian mangroves occupies the second largest extent in the world $\left(13,000 \mathrm{~km}^{2}\right)$, corresponding to $8.5 \%$ of the global mangrove area (Spalding et al. 2010). Despite this, mangrove areas worldwide have been decreased, particularly due to intensification of the anthropogenic activities (Polidoro et al. 2010), in special those related to agriculture, aquaculture, property expansion, exploitation of coal/wood, among others (FAO 2007). This habitat loss directly impacts the mangrove macrofauna, especially $U$. cordatus which shows biologic limitations as slow growth and high fishery exploitation. This scenario has drawn the attention of researchers that previously studied the abundance and density of this crab species in Brazilian mangroves of the northnortheastern (Alcântara-Filho 1978, Amaral et al. 2014, Costa 1979, Santos et al. 2016) and southsoutheast (Blankensteyn et al. 1997, Sandrini-Neto and Lana 2012, Wunderlich et al. 2008), as well as national environmental agencies responsible for the conservation and sustainable fishery of this species (e.g., Dias-Neto 2011).

Density estimates in crustaceans can vary in function of their activity, spatial distribution and habitat. In semi terrestrial crabs these estimates could be indirect, conducted by counting the number of active individuals or using the number of galleries/area, for non digging and digging species, respectively (Macia et al. 2001). For U. cordatus, it is known the existence of only one exemplar/ gallery (Costa 1979, Pinheiro and Fiscarelli 2001), a fact that makes possible more reliable evaluations, mainly considering the discount of galleries without biogenic activities (abandoned) and those with more of one aperture, which percentage is still unknown in the literature. Therefore, information about crustacean density is relevant to crustaceans with economic importance (Pérez-Chi 2005, Saher and Qureshi 2011, Waiho et al. 2015), although there are few quality data in the literature about this subject (Alberts-Hubatsch et al. 2016), specially for $U$. cordatus, preventing accurate estimates of abundance.

In Brazil Southeast, the mangroves of Iguape municipality are part of the Environmental Protected Area (EPA) from Cananéia-IguapePeruíbe (EPA/CIP), and are characterized by a good conservation status, assuring a sustainable extraction of the 'uçá'-crab and others estuarine fishery resources. Density estimates and 
characterization of population structure of this crab are scarce in this region (e.g., Hattori 2006), but they are essential aspects to evaluate the crab extractive potential and quantity of the stocks. This information could be a temporal mark to monitor this species, thus very important to be considered in the Proposal of a National Management Plan for the Sustainable Use of Ucides cordatus, in the light to designate mangroves areas for exclusion and crab extraction (Dias-Neto 2011). This study evaluates the population structure, density, abundance and extractive potential of $U$. cordatus at Iguape mangroves, using percentages of bias and mortality pre-established. Based on this, it was discussed possible projections about sustainable extraction of this species at local scale and the applicability of these parameters at the national scale for the crab fishery management.

\section{MATERIALS AND METHODS}

The density, abundance and extractive potential of $U$. cordatus were estimated in mangrove areas with predominance of the white-mangrove
Laguncularia racemosa (L.) Gaertn.f., (>80\%), in an estuarine island near to Icapara Foz, Iguape Municipality, São Paulo State, Brazil (Figure 1). During one completed year (September 1998 to August 1999), a same mangrove area was monthly sampled to obtain data about population density of $U$. cordatus. A sample unit measuring $2 \times 2 \mathrm{~m}$ was considered the ideal quadrat due to minimize the product between the variance and time, according Wiegert's method (e.g., Krebs 1999).

The density of $U$. cordatus was monthly represented by the average of five $2 \times 2 \mathrm{~m}$ sample quadrats totalizing $20 \mathrm{~m}^{2}$, with the first of them placed $10 \mathrm{~m}$ from the mangrove margin and the others contiguous and perpendicularly placed inside to the mangrove forest (Figure 1). In the first month the quadrats were positioned $50 \mathrm{~m}$ from the NE (Northeast) island edge, and in the subsequent months they were disposed in direction to SW (Southwest), always with $20 \mathrm{~m}$ of distance each month (Figure 1). The crab density was registered by counting of numbers of galleries $/ \mathrm{m}^{2}$, considering

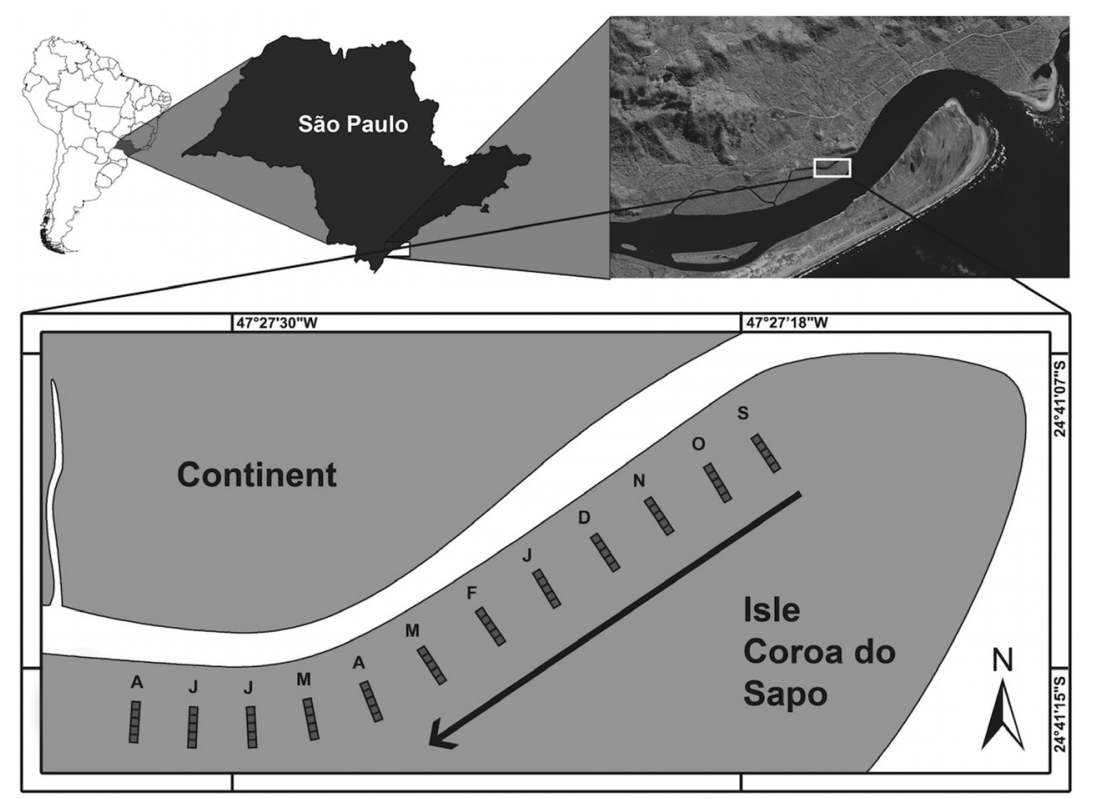

Figure 1 - Location and execution sequence (arrow) of the mangrove areas monthly sampled from September 1998 to August 1999, at 'Coroa do Sapo' Island, Municipality of Iguape, São Paulo State, Brazil. Where letters correspond to initial of each month; and art design by Gustavo Pinheiro based on Ikonos IV image. 
the occurrence of only one exemplar/gallery (Costa 1979, Pinheiro and Fiscarelli 2001). To minimize the estimative bias of density (and other population parameters to be evaluated) only the crab galleries with a sloping position in relation to the sediment surface were counted, which characterize $U$. cordatus gallery (see Santos et al. 2009). It was used the method established by Pinheiro and Almeida (2015), by which only opened galleries with biogenic activity (e.g., presence of traces and/ or with mud near the gallery overture) or closed (gallery overture recently occluded by mud or not removed) were counted, discarding those without biogenic activities (abandoned). The duct of each gallery was also accompanied by hand to verify the existence of one or more overtures, aiming to minimize this bias at the final counting.

To compare the density among mangrove areas (treatments) it was applied ANOVA considering five quadrats as replicates, with contrast 'a posteriori' by Tukey test in a 5\% significance level. To use ANOVA it was verified the assumptions by the normality Shapiro-Wilk test and regression residue analysis (Quinn and Keough 2002). Monthly in the same mangrove area where the quadrats were installed, the flooding level by tides $(F)$ was measured based on the vertical distribution of the macroalgae ("Bostrychietum") on the base of the mangrove tree trunks $(n=15)$, using a measuring tape (in centimeters). The flooding tide average was associated with the average of crab density, using Spearman's correlation coefficient with $5 \%$ of significance level. To verify a possible heterogeneity of flooding among the mangrove areas monthly sampled, the data were firstly submitted to a normality test (SW, Shapiro-Wilk) and then to a homoscedasticity test of variances (L, Levene's test), used as assumptions to apply a statistical test evolving averages (ANOVA) or, in antagonism, a non parametric test (KW, KruskalWallis) (Sokal and Rohlf 1995).
The instantaneous total mortality rate $(Z)$ and survival annual tax $(S)$ were obtained based on the monthly distribution of frequency by the crab size class ( $\mathrm{CW}$, carapace width). The calculation of ' $\mathrm{Z}$ ' was obtained using the method of length-converted catch curves (Pauly 1983, 1984a, b), while 'S' was calculated by the equation $\exp (-Z)$ (Ricker 1975). These values were used to improve the abundance estimates with the necessary discounts. The population abundance of $U$. cordatus was based on the product between the estimated mangrove area and the average crab density. The estimated mangrove area was obtained in the study of Herz (1991), who elaborated mangrove maps for the study area occurring between 'Icapara' Foz (243' 30' S) and 'Boqueirão' Island (2445'30' S), using synthetic aperture radar images from 1985.

The diameter of the opened galleries (DG) inside the quadrats was measured with a vernier caliper as indicated by Pinheiro and Almeida (2015) and converted to carapace width (CW) using the equation $\mathrm{CW}=13.21+0.9602 \cdot \mathrm{DG}\left(\mathrm{R}^{2}=\right.$ 0.73), established to Brazilian southeastern-south regions for $U$. cordatus. These data were used to characterize the crab population structure (mean size and size-frequency distribution) and to calculate the immediate extractive potential (IEP) which is the percentage of crabs with carapace width equal or higher than $60 \mathrm{~mm}(\mathrm{CW} \geq 60 \mathrm{~mm})$ and the future extractive potential (FEP) which is the percentage of crabs with carapace width lower than $60 \mathrm{~mm}(\mathrm{CW}<60 \mathrm{~mm})$ (e.g., Wunderlich et al. 2008). These parameters were established based on the Brazilian legal minimum market size of $U$. cordatus, which is $60 \mathrm{~mm}$ of carapace width (IBAMA 2003a, b).

\section{RESULTS}

A total of 1,411 crabs were recorded in the mangroves of Iguape, with a density ranging from 2 
to 11 ind. $\mathrm{m}^{-2}$, and an average of $6 \pm 2$ ind. $\mathrm{m}^{-2}$ (Table I and Figure 2a). The density data showed normal distribution ( $\mathrm{SW}=0.976, p=0.285$ ), leading to an analysis of variance in function of the mangrove sampled area. The ANOVA reveled that $72.7 \%$ of the total crab density variance was explained by the mangrove areas which significantly differed among them $\left(\mathrm{F}=11.63 ; p=3.6810^{-10}\right)$. Based on the differences of mean crab density among the areas, they were grouped and divided into three groups: A (areas 01 to 03 ), B (areas 04 to 08 and 12) and C (areas 09 to 11). This new arrangement was again assessed by ANOVA $\left(\mathrm{F}=53.3 ; p=8.2710^{-14}\right)$, which confirmed a significant difference on the crab density among the groups (Table II, Figure 2b). The highest difference occurred between groups A and B (Table II), which showed the lowest and highest crab densities, respectively (Figure 2b).

TABLE I

Flooded height $(\mathrm{cm})$ of tides estimated based on the vertical distribution of 'Bostrychietum' on mangrove arboreal base, in each mangrove area monthly sampled during one year (September 1998 to August 1999), and respective densities of $U$. cordatus, based on gallery number in function of its condition $(\mathrm{O}$, opened; $\mathrm{C}$, closed; $\mathrm{T}$, total).

\begin{tabular}{|c|c|c|c|c|c|c|}
\hline \multirow{2}{*}{ Mangrove Area } & \multirow{2}{*}{ Month/Year } & \multicolumn{2}{|c|}{ Flooded height $(\mathrm{cm})$} & \multicolumn{3}{|c|}{ Mean of galleries. $\mathrm{m}^{-2}$} \\
\hline & & Mean \pm SD & CV (\%) & $\mathrm{O}$ & $\mathrm{C}$ & $\mathrm{T}$ \\
\hline A01 & Sep/1998 & $23.3 \pm 8.7$ & 37.2 & 2 & 0 & 2 \\
\hline $\mathrm{A} 02$ & Oct & $14.8 \pm 2.2$ & 14.8 & 3 & 1 & 4 \\
\hline A03 & Nov & $19.4 \pm 3.2$ & 16.3 & 2 & 1 & 3 \\
\hline A04 & Dec & $18.4 \pm 3.3$ & 17.8 & 7 & 0 & 7 \\
\hline A05 & Jan/1999 & $17.1 \pm 2.9$ & 17.1 & 6 & 1 & 7 \\
\hline A06 & Feb & $17.2 \pm 3.5$ & 20.3 & 6 & 2 & 7 \\
\hline A07 & Mar & $14.8 \pm 3.8$ & 25.4 & 5 & 3 & 8 \\
\hline A08 & Apr & $11.4 \pm 4.4$ & 38.6 & 5 & 3 & 9 \\
\hline A09 & May & $21.9 \pm 3.0$ & 13.9 & 5 & 0 & 5 \\
\hline A 10 & Jun & $10.4 \pm 3.7$ & 35.3 & 4 & 1 & 5 \\
\hline A11 & Jul & $23.1 \pm 4.7$ & 20.3 & 5 & 1 & 6 \\
\hline A12 & Aug & $14.8 \pm 3.2$ & 21.8 & 7 & 1 & 7 \\
\hline \multicolumn{2}{|c|}{ Mean \pm SD } & $17.2 \pm 4.2$ & & $5 \pm 2$ & $1 \pm 1$ & $6 \pm 2$ \\
\hline \multicolumn{2}{|c|}{ CV (\%) } & 24.6 & & 36.5 & 92.0 & 34.6 \\
\hline
\end{tabular}
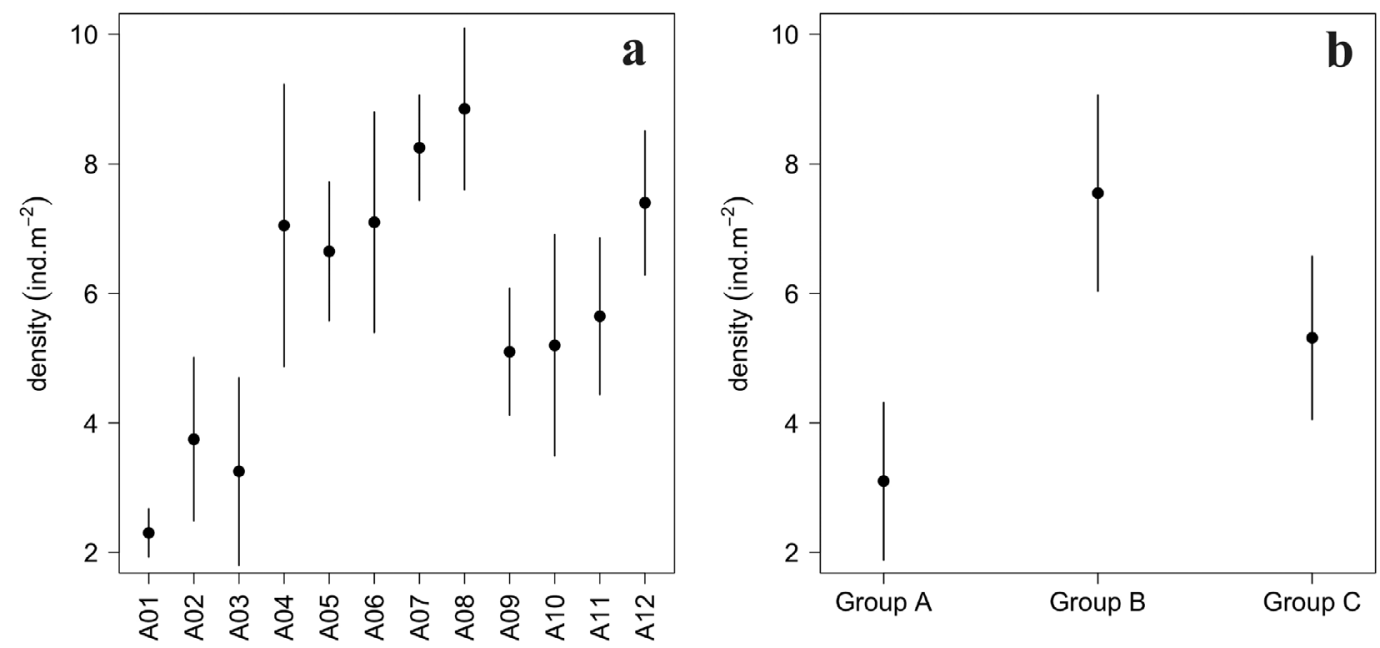

Figure 2 - Mean ( \pm standard deviation) of Ucides cordatus density in Iguape (SP) mangroves, in each sampled area (a), and based on three groups (b) established. Where: Group A (areas A01 to A03); Group B (areas A04 to A08 and A12); and Group C (areas A09 to A11). 
This analysis revealed a spatial pattern in which the crab population occurs at lower densities in the extremities NE (group A) and SW (group C) of the isle, and at higher densities in the central region of the isle (group B).

On the assumption that the flood influences the density of crabs, a simple regression model was tested, considering the means of flood $(F)$ and the density of the crab in the twelve mangrove areas (D). The initial model for the relationship $D$ vs. $F$ showed a moderate negative correlation between these variables (Figure $3 \mathrm{a})(\mathrm{r}=-0.50, \mathrm{df}=10$, $p=0.09$ ), but it slightly explained the variation of density due to flooding $\left(\mathrm{R}^{2}=0.25\right)$. In the residual analysis, it was identified the presence of four outlier points (areas 01, 02, 03 and 10) (Figure $3 a)$ which were removed for a further evaluation

TABLE II

Differences in crab density (ind. $\mathrm{m}^{-2}$ ) among the groups of mangrove areas (A, Areas 01-03; B, Areas 04-08 and 12; and $C$, Areas 09-11) using information of Tukey test.

\begin{tabular}{ccccc}
\hline \multirow{2}{*}{ Group } & \multirow{2}{*}{$\begin{array}{c}\text { Mean } \\
\text { difference }\end{array}$} & \multicolumn{2}{c}{ Confidence interval } & \\
\cline { 3 - 4 } & & Lower & Upper & \\
\hline B $-\mathrm{A}$ & 4.45 & 3.39 & 5.50 & 0.000 \\
$\mathrm{C}-\mathrm{A}$ & 2.21 & 1.00 & 3.43 & $1.4610^{-4}$ \\
$\mathrm{C}-\mathrm{B}$ & -2.23 & -3.28 & -1.18 & $1.1710^{-5}$ \\
\hline
\end{tabular}

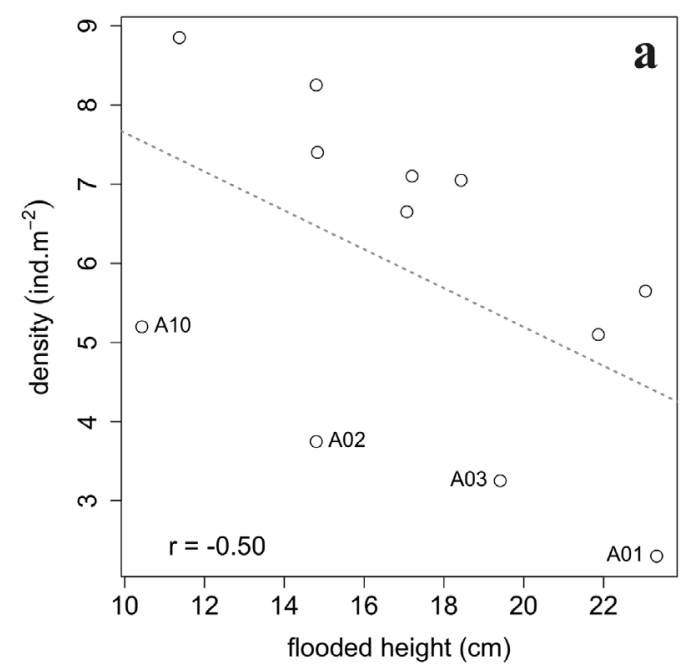

of the model. In this second analysis the model showed a high negative correlation between the variables (Figure $3 \mathrm{~b})(\mathrm{r}=-0.94, \mathrm{df}=6, p=0.0003)$ and significantly explained the variation of density areas due to flooding $\left(\mathrm{R}^{2}=0.89\right)$. Therefore, the relationship $D$ vs. $F$ indicated that $U$. cordatus density tend to decline in mangroves with higher level of flooding by tides, which correspond to the mangrove areas distributed at the extremities of the isle.

The total mortality rate $(Z)$ of $U$. cordatus in Iguape mangroves was estimated in $1.05 \pm 1.15 \mathrm{yr}^{-1}$, resulting in $34.8 \%$ survivors/year (Figure 4 ). The natural mortality $(\mathrm{M})$ was estimated in $0.49 \mathrm{yr}^{-1}$, while the fishery mortality $(\mathrm{F})$ was $0.56 \mathrm{yr}^{-1}$, with an exploitation rate of 0.533 , therefore, the fishery of this resource is responsible for $53.3 \%$ of the crab mortality. The mean size of $U$. cordatus, estimated in terms of carapace width, was $49.6 \pm 10.5 \mathrm{~mm}$. Most of the crabs were in the class size of 40 to 50 $\mathrm{mm}(40.3 \%)$, followed by the class of 50 to $60 \mathrm{~mm}$ (24.4\%) and 30 to $40 \mathrm{~mm}(16 \%)$ (Figure 5a). Thus, small to medium sized crabs (30 to $60 \mathrm{~mm}$ ) were the most frequent in the mangroves of the Iguape. Larger crabs (60-70 mm: 14.2\%; 70-80 mm: 3.7\%;

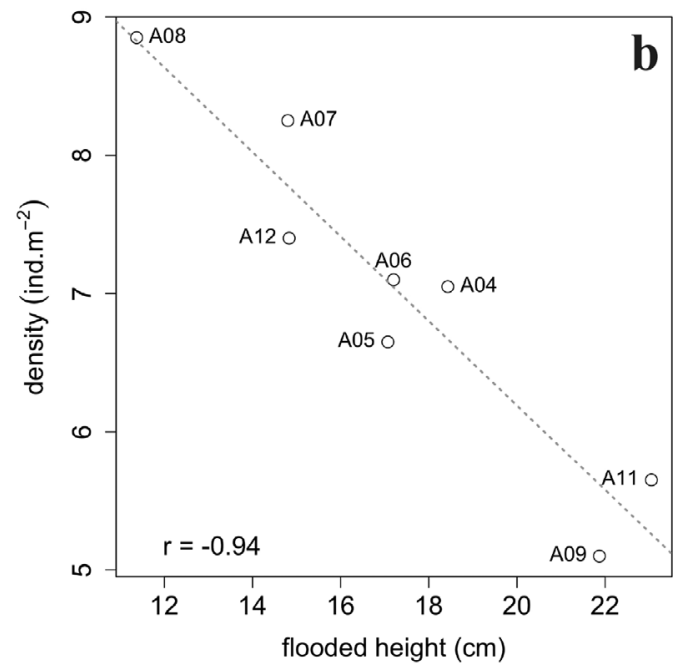

Figure 3 - Relationship between Ucides cordatus density (ind. $\mathrm{m}^{-2}$ ) and flooding height $(\mathrm{cm})$, with identification of four outlier points removed of the analysis (a), and the remaining points used to data reanalysis (b). 
and $80-90 \mathrm{~mm}: 0.39 \%$ ) were less frequent in these mangroves (Figure 5a).

In overall, only $18.2 \%$ of the total crabs were in commercial size $(\mathrm{CW} \geq 60 \mathrm{~mm})$, while $81.8 \%$ were crabs that did not reach commercial size $(\mathrm{CW}<60 \mathrm{~mm})$. Therefore, in the mangroves of the studied area the Immediate Extractive Potential IEP of $U$. cordatus was significantly lower than the Future Extractive Potential - FEP (Figure 5b).

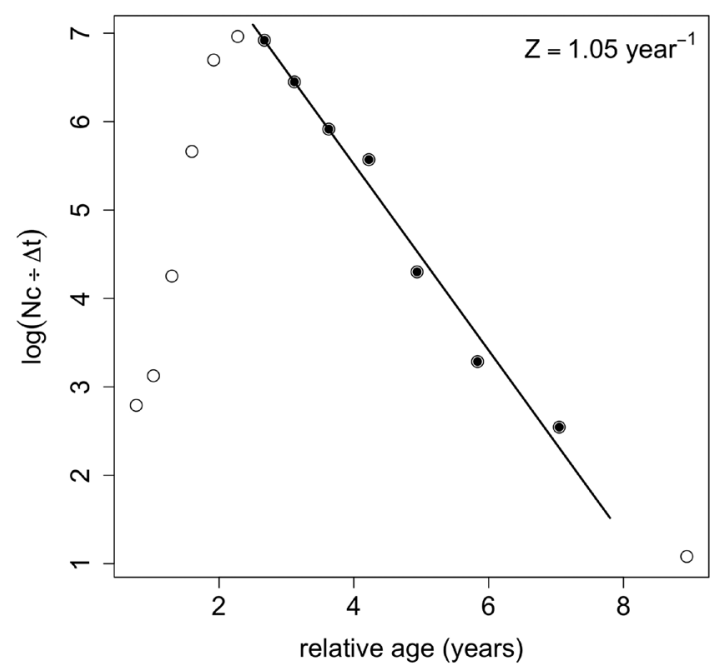

Figure 4 - Total mortality $(\mathrm{Z})$ estimated to $U$. cordatus at Iguape (SP).

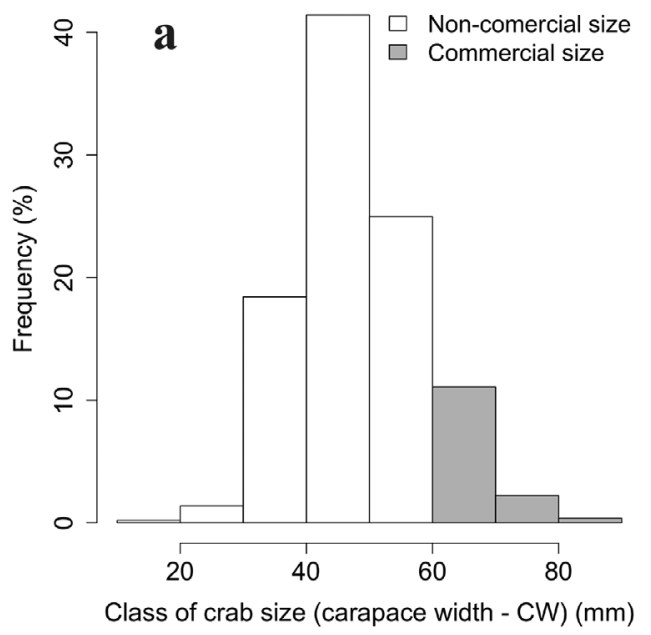

This indicates that the population of $U$. cordatus at the studied mangrove areas was most composed of small and juvenile crabs that did not reached the commercial size (Figure 5).

According to the data obtained by Herz (1991), the municipality of Iguape (SP) comprised a total mangrove area of $28.7 \mathrm{~km}^{2}$ (Table III). Considering this fact and the mean density of $U$. cordatus in the study area $\left(6 \pm 2\right.$ ind. $\left.\mathrm{m}^{-2}\right)$, the total absolute abundance of $U$. cordatus in Iguape mangroves was 172.5 millions of crabs. However, this abundance was reduced to 60 millions of crabs if we considered the discount of $65.2 \%$ of mortality tax of this species (Table III).

Considering the mangrove forest status in Iguape, $68.8 \%$ were pristine areas, while $31.2 \%$ were anthropized (Table III). Based on this, the total and corrected crab abundances were extremely higher in the pristine areas than in the anthropized mangroves (Table III). In regard to mangrove forest categories, most of them $(50.7 \%)$ were located in less-flooded areas (high mangroves), which showed higher values of total and corrected crab abundances than the more-flooded areas (low mangroves - 18.2\%) (Table III). On the other

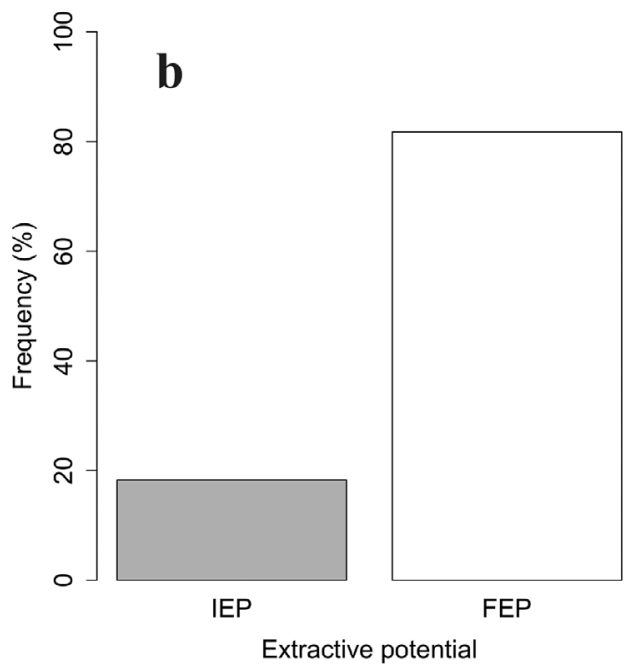

Figure 5 - Population and fishery parameters of $U$. cordatus in the mangroves of Iguape. (a) Sizefrequency distribution by carapace width classes. (b) Immediate Extractive Potential (IEP) and Future Extractive Potential (FEP). 
TABLE III

Areas and status of mangrove forests related to the absolute abundance of

$U$. cordatus, using the mean density $\left(6 \pm 2\right.$ ind. $\left.\mathrm{m}^{-2}\right)$ without correction (TCA, total crab abundance), and discounting $65.2 \%$ of mortality (CCA, corrected crab abundance). Source of mangrove categories and status from Herz (1991), where: H, high; L, low; D, degraded; and A, altered.

\begin{tabular}{|c|c|c|c|c|c|c|c|c|}
\hline \multirow{2}{*}{$\begin{array}{l}\text { Map Code } \\
\text { Herz (1991) }\end{array}$} & \multirow{2}{*}{ Locality } & \multicolumn{4}{|c|}{ Mangrove Categories ${ }^{1}\left(\mathrm{Km}^{2}\right)$} & \multicolumn{3}{|c|}{ Mangrove Status ${ }^{2}\left(\mathrm{Km}^{2}\right)$} \\
\hline & & $\mathrm{H}$ & $\mathrm{L}$ & $\mathrm{D}$ & A & Pristine & Anthropized & Total \\
\hline $37647 J 1$ & Barra Ribeira & 0.009 & - & - & - & 0.009 & - & 0.009 \\
\hline $37647 \mathrm{~J} 2$ & Barra Ribeira & 0.231 & - & - & - & 0.231 & - & 0.231 \\
\hline $37647 \mathrm{~J} 3$ & Barra Ribeira & 1.100 & 0.300 & - & 0.200 & 1.400 & 0.200 & 1.600 \\
\hline $37647 \mathrm{~J} 4$ & Barra Ribeira & 6.067 & 3.238 & 0.158 & 0.185 & 9.305 & 0.343 & 9.648 \\
\hline $37647 \mathrm{~K} 3$ & Iguape & 2.316 & 1.679 & 2.148 & 6.275 & 3.995 & 8.423 & 12.418 \\
\hline $37647 \mathrm{~K} 4$ & Iguape & 4.837 & - & - & - & 4.837 & - & 4.837 \\
\hline \multicolumn{2}{|c|}{ Mangrove Area $\left(\mathrm{Km}^{2}\right)$} & 14.6 & 5.2 & 2.3 & 6.7 & 19.8 & 9.0 & 28.7 \\
\hline \multicolumn{2}{|c|}{ Mangrove Area (\%) } & 50.7 & 18.2 & 8.0 & 23.2 & 68.8 & 31.2 & 100.0 \\
\hline \multicolumn{2}{|c|}{$\operatorname{TCA}\left(x 1^{6}\right)$} & 87.4 & 31.3 & 13.8 & 39.9 & 118.7 & 53.8 & 172.5 \\
\hline \multicolumn{2}{|c|}{$\operatorname{CCA}\left(x 1^{6}\right)$} & 30.4 & 10.9 & 4.8 & 13.9 & 41.3 & 18.7 & 60.0 \\
\hline
\end{tabular}

hand, there were more altered mangroves (23.2\%) that showed higher values of total and corrected crab abundances than the degraded mangroves (8\%) (Table III). This scenario, in which $31.2 \%$ of mangroves were influenced by anthropogenic activities and sheltered $U$. cordatus populations, can have a directed impact in the quality of the resource found in these areas. Moreover, considering that only $18.2 \%$ of the $U$. cordatus in the study area is in commercial size, the total and corrected crab abundances drastically decreased to 31.4 and 10.9 millions of crabs, respectively.

\section{DISCUSSION}

\section{DENSITY AND ABUNDANCE OF U. cordatus}

The density of $U$. cordatus varied significantly between the mangrove areas $\left(3\right.$ ind. $\mathrm{m}^{-2}$ in NE, 8 ind. $\mathrm{m}^{-2}$ in the inner, and 3 ind. $\mathrm{m}^{-2}$ in SW), with a mean of $6 \pm 2$ ind. $\mathrm{m}^{-2}$. Comparing these values with those recorded by studies in others Brazilian mangroves, it was found that the study area showed similar values of $U$. cordatus density of those recorded in North Brazilian, as by Piou et al. (2009), who recorded an average crab density of 6.02 ind. $\mathrm{m}^{-2}$, in the mangroves of Pará state. Nevertheless, in overall, the mangroves of Iguape (study area) showed higher crab density than others mangroves along the Brazilian coast. For example in the northeast coast, the maximum crab density was between 4 to 5 ind.m ${ }^{-2}$ (e.g., AlcântaraFilho 1978, Blankensteyn et al. 1997, Costa 1979, Nascimento et al. 1982) while the minimum was between 1.2 to 1.7 ind. ${ }^{-2}$ (Alves and Nishida 2004, Santos et al. 2016). It is interest to highlight that the mangroves of Iguape recorded higher values than those found in mangroves on the southeast coast, the region where the study area is located. For example, the maximum crab density of 3.7 ind. $\mathrm{m}^{-2}$ was recorded by Goes et al. (2010) in mangroves of the Espírito Santo State, while the smallest value of 0.85 ind. $\mathrm{m}^{-2}$ was recorded by Sandrini-Neto and Lana (2012), in mangroves of the Paraná State. In other location of the same study area Hattori (2006) recorded average densities of 3.9 ind $\mathrm{m}^{-2}$, which is lower than those in this study.

It is remarkable that $U$. cordatus density can vary between different mangrove areas as a result of their degradation (Duarte et al. 2014, Pinheiro et al. 2013), higher incidence of fishery (Pinheiro 
and Fiscarelli 2001), as well as due to intrinsic factors of a particular mangrove forest type as vegetation composition and flood degree (Conti and Nalesso 2010). Although Wolff et al. (2000) have indicated that predators of $U$. cordatus (e.g., raccoons, monkeys, and caracara hawks) generally occur in low abundance in mangrove areas and do not influence the abundance and density of this crab species, a different pattern is registered at Iguape mangroves. In this area, fisherman have report that raccoons are abundant and prey on $U$. cordatus crabs, therefore reducing the abundance and density of this crab species and influencing in the fishery activity, since the raccoons prey on the crabs captured by the tangle-netting traps.

In this view, the higher values of crab density recorded in the mangroves of Iguape during 1998 to 1999 , can be correlated to three factors. Firstly, in the study area the fishery of $U$. cordatus during that period was almost non-existent and did not influence the observed crab abundance. This is not the reality of others Brazilian mangroves where the fishery is an intense activity (e.g., Alves and Nishida 2003, Firmo et al. 2011, Glaser and Diele 2004, Passos and Di Beneditto 2005, Santos et al. 2016, Souto 2007). Thus without fishery pressure on that period, the abundance of $U$. cordatus in Iguape was very high. Secondly, most of the mangroves of the study area during the final of 90's were pristine areas $(68.8 \%$ ), which provided a good habitat quality, food availability (vegetation litter) and high habitat extent for the development of $U$. cordatus population, thus supporting higher crab densities. Finally, the mangroves of the study area are dominated by the plant species Laguncularia racemosa $(>80 \%)$, thus this can influence the crab population structure and density, leading to the higher densities here recorded. For example, Piou et al. (2009) showed that $U$. cordatus preferentially created their burrow entrances closed to $R$. mangle prop roots, in which is found lower total crab density, but of large crabs. Presence of L. racemosa in the neighborhood does not favor big crabs (Piou et al. 2009), thus small crabs in higher densities dominate these mangroves. This can be attribute to the morphological characteristics of L. racemosa which has cable roots that run under the surface of the mud and many pneumatophores coming up the surface, which can difficult the built of galleries by larger crabs, but are more appropriate for small crabs that can occur in high densities, as it was observed.

Although Macia et al. (2001) and Skov et al. (2002) pointed out that the evaluation of crab density by counting galleries may overestimate this population parameter by $20 \%$, these authors emphasize that this method is much more effective when compared to the gathering of the crabs. Advantages of this methodology includes: speed and consequent increase in sample size; conducting non-destructive sampling, important when work involves endangered species and the possibility of obtaining measures of all individuals within sampling units (Schmidt et al. 2008). Population estimations from gallery numbers and size have been widely used for mangrove crab species (e.g., Kent and McGuinness 2006, Macintosh 1988, Skov et al. 2002, Warren 1990), including U. cordatus (Alcântara-Filho 1978, Alves and Nishida 2003, Firmo et al. 2011, Hattori 2006, Piou et al. 2009, Sandrini-Neto and Lana 2012, Schmidt et al. 2008, Wunderlich et al. 2008) with high rates of accuracy.

A significant high negative correlation was found between the flood height and the crab density (Figure 3b). A spatial distribution pattern was observed with a zone of lower abundance (mean of 3 ind. $\mathrm{m}^{-2}$ ) located in the NE of the island (moreflooded); followed by higher abundances (mean of 8 ind. $\mathrm{m}^{-2}$ ) in the inner of the island (less-flooded), and lower abundances (mean of 5 ind. $\mathrm{m}^{-2}$ ) in the SW of the island (more-flooded). Based on the regression model (Figure $3 b$ ) the effect of flooding on the crab abundance can be understood, since the more flooded areas showed low abundance of crabs, and 
the less-flooded areas higher abundance, showing a dependence of crab density on the flooding height $(\mathrm{r}=-0.94 ; \mathrm{df}=6 ; p=0.0003)$. Therefore, $89 \%$ of the variation on crab density was explained by flood height $\left(\mathrm{R}^{2}=0.89\right)$. Corroborating with these results, Conti and Nalesso (2010) found that higher $U$. cordatus densities occur in mangrove areas with low salinity, showing a negative correlation between these variables. In this context, it is expected that more-flooded mangroves should present higher salinity, and therefore lower density of crabs.

Data from previous studies M.A.A. Pinheiro et al. (Unpublished results), Santos et al. 2016, Wunderlich and Pinheiro 2013) suggest that mangrove forests dominated by $L$. racemosa are those located in areas of high microtopography, thus with lower levels or frequency of flooding during neap and spring tides and are muddy areas showing more compacted sediment. Thus, in these areas, small crabs are more able to rebuild their galleries, than the large ones that preferably habit $R$. mangle dominated mangrove (e.g., Piou et al. 2009, Santos et al. 2016). Smaller crabs colonize Laguncularia racemosa less-flooded mangroves, therefore these mangroves are able to support higher crabs densities.

For the $U$. cordatus population of the Iguape mangroves, the total mortality $(Z)$ was $1.05 \mathrm{y}^{-1}$, which is very higher than those estimated by Diele and Koch (2010) as $0.56 \mathrm{y}^{-1}$ and $0.53 \mathrm{y}^{-1}$ for females and males, respectively, in North Brazil and than those estimated by Farias (2009) as 0.60 and 0.57, respectively, in the Northeastern Brazil. The higher total mortality found in Iguape mangroves can be attributed to the structure of the crab population which is most composed by small sized crabs, $56.3 \%$ of crabs with carapace width between 30 to $50 \mathrm{~mm}$, differing from the others studies (e.g., Diele and Koch 2010, Farias 2009). This high crab mortality causes a high reduction in the crab abundance and its stocks.
The mean size of $U$. cordatus recorded at the Iguape mangroves $(49.6 \pm 10.5 \mathrm{~mm})$ was very similar to those recorded by other authors in the southeast Brazilian coast (45.9 mm - Conti and Nalesso 2010; and $48.9 \mathrm{~mm}$ - Hattori 2006). Nevertheless, this mean size was lower than those recorded by other authors in the north and northeast Brazilian coast (50.5 to $64.4 \mathrm{~mm}$ : Alcântara-Filho 1978, Alves and Nishida 2004, Amaral et al. 2014, Diele et al. 2005, Piou et al. 2009), as well as extremely lower than in the southeast coast (58.7 to $68 \mathrm{~mm}$ : Wunderlich et al. 2008). In the Iguape mangroves a dominance of small crabs (30 to 60 $\mathrm{mm}$ ), mainly from the class of 40 to $50 \mathrm{~mm}$, was found. This pattern differed from those recorded in other studies about $U$. cordatus in Brazilian mangroves (e.g., Dias-Neto 2011, Diele et al. 2005, Passos and Di Beneditto 2005, Santos et al. 2016), which found a dominance of adult medium size crabs (40 to $70 \mathrm{~mm}$ ).

\section{FISHERY POTENTIAL AND MANAGEMENT OF $U$. cordatus}

Ucides cordatus is a species with low growth rate, high age of maturity, reaching the commercial size $(\mathrm{CW}=80 \mathrm{~mm}$ ) around 7 to 8 years (Pinheiro et al. 2005, Pinheiro and Fiscarelli 2001). These features indicate that the population stocks of the species are subject to significant reduction if submitted to high fishery pressure without adequate management, which would undermine the continuity of their extraction, and as a consequence, the economic subsistence of human populations along the Brazilian coast. This highlights the importance of stock assessments of this species, in the current and past periods, in order to generate data about the stock changes and status, which will allow the development of fishery management strategies.

Since the end of 90's, the fishery of $U$. cordatus has been in the attention of Brazilian environmental agencies. To illustrate, in 1998 a management group of this resource was created for the south 
and southeast regions of Brazil, coordinated by the Brazilian Institute of Environment and Renewable Natural Resources (IBAMA), when the first regional ordinance was published with a fishing closed season for this species. Since this ordinance has been published, it was subjected to four adjustments, and the last one was published in 2003 (IBAMA 2003b). From this, in 2004, U. cordatus was included in the list of overfished or endangered species of overexploitation by the Normative Instruction \# 05/2004 of the National Environment Ministry. Despite this legal framework, published data (e.g., Alves and Nishida 2004, Boeger et al. 2005, Dias-Neto 2011, Diele et al. 2005, Jankowsky et al. 2006) have documented a significant reduction of the natural stocks, indicating the urgent need for population management of this crab. Consequently, in 2011, the IBAMA published a Proposal of a National Management Plan for the Sustainable Use of Ucides cordatus. More recently, in the end of 2014, the National Environment Ministry published the Ordinance \# 445/2014, in which U. cordatus was listed in the "near threatened" (NT) category (Pinheiro et al. 2016). Finally, in 2015, this crab was included in the National Conservation Action Plan of Endangered Species and of Socioeconomic Importance in Mangrove Ecosystems (PAN Mangrove - Ordinance \# 9 of January 29, 2015), as one of the nine species listed in the regional list of endangered species.

The Proposal of a National Management Plan for the Sustainable Use of U. cordatus (Dias-Neto 2011) aims to promote the sustainable use of this resources, ensuring the maintenance of populations at satisfactory levels, allowing the continuity of economic activity (Pinheiro and Rodrigues 2011). For this, it is necessary the evaluation of $U$. cordatus stocks and of its extraction potential, as estimated in this study.

Here it was found a high total and corrected absolute abundance of $U$. cordatus (172.5 and 60 millions of crabs, respectively), which is an estimate of the crab stocks for the entire area, in $1998 / 1999$, considering the mangrove extent based on imagery from 1985 (Herz 1991). Nevertheless, more recently, an analysis of Landsat images from 2010, carried by Cunha-Lignon et al. (2011), for Iguape mangroves, with the exception of the Vila Subauma, estimated a total mangrove area much lower $\left(10.61 \mathrm{~km}^{2}\right)$ than those recorded by Herz (1991), which was $28.7 \mathrm{~km}^{2}$. This figure comprised $36.9 \%$ of the area estimated by Herz (1991), reflecting in lower values for TCA (63.7 millions of crabs) and CCA (22.2 millions of crabs).

In regard to the potential extraction, the IEP (18.2\%) was extremely lower than the FEP (81.8\%) in the study area. Therefore, considering that only $18.2 \%$ of $U$. cordatus population in the study area is in commercial size, the abundances have drastically decreased to $31.4 \cdot 10^{6}$ (TCA) and $10.9 \cdot 10^{6}$ crabs (CCA) according to mangrove extent data from Herz (1991); and to $11.6 \cdot 10^{6}$ (TCA) and $4 \cdot 10^{6}$ crabs (CCA), according to the data from CunhaLignon et al. (2011).

Hattori (2006) have recorded an IEP of $34.3 \%$ and a FEP of $65.7 \%$ for the same area in 2004/2005. These findings of Hattori (2006) and the results of the present study suggest that the study area mangroves tend to show a pattern of high FEP and low IEP. To illustrate, after having spent seven years (1998 to 2005), which is very close to the period that $U$. cordatus reaches the commercial size ( 7 to 8 years) (Pinheiro et al. 2005, Pinheiro and Fiscarelli 2001), the IEP had an increment of $16.1 \%$ (18.2\% in 1998 to $34.3 \%$ in 2005). This configures an annual rate of $2.3 \%$ of increment in IEP. Based on these results, the study area requires a high attention, in order to protect the crab population that does not reach the commercial size.

Therefore, according to these features and the strategies stated in the Proposal of a National Management Plan for the Sustainable Use of Ucides cordatus (Dias-Neto 2011), it is suggested that the study area should be categorized as an exclusion 
area (e.g., Dias-Neto 2011), which is more suitable for the conservation of the crab population. In this area the crab fishery should be prohibited, in order to allow the conservation of adult crabs for reproduction, enabling the juvenile crabs to grow and reach the commercial sizes, which is very important to maintain the population stocks.

\section{CONCLUSIONS}

This study concludes that the density and abundance of $U$. cordatus in mangrove areas are influenced by abiotic, biotic and anthropogenic factors. Among them it is highlighted flood tide level, fishery pressure, mangrove conservation status and mangrove vegetation composition. The crab abundance and density tend to be higher in less-flood mangroves, when fishery pressure is low or absent, when mangroves show a good conservation status and their vegetation is dominated by Laguncularia racemosa. The flood tide level shows a negative correlation with the crab density; therefore, higher flood level is associated with lower crab density. Considering an isle of mangrove, which is very common in this ecosystem, this configures a spatial pattern wherein the crab population occurs at lower densities in the less-flood areas.

The study stresses the importance to consider the crab mortality tax in order to evaluate the corrected $U$. cordatus abundance, which is major for stock assessment. Decrease in mangrove extent due to anthropogenic factors has a direct impact in the crab abundance, causing a high reduction in total and corrected abundances, due to habitat loss. This highlights the need for the conservation of mangrove habitats in order to maintain $U$. cordatus stocks.

Mangrove areas most composed by small crabs of $U$. cordatus, with carapace width between 30 to $60 \mathrm{~mm}$, tend to show high future extractive potential (FEP) and low immediate extractive potential (IEP). Since Ucides cordatus show low growth rate this pattern in extractive potentials tend to change at a low annual rate for IEP increment. Therefore, considering the Proposal of a National Management Plan for the Sustainable Use of Ucides cordatus, mangroves showing these features should be designated as exclusion areas in order to allow juvenile crabs grow and reach the commercial sizes, which is very important to promote a sustainable fishery. Finally, it was concluded the importance of long-term data about the population structure of $U$. cordatus, including comparison of past and current data, as base to designate exclusion and extractive areas in the National Management Plan for the Sustainable of this species.

\section{ACKNOWLEDGMENTS}

The authors would like to thank the Fundação de Amparo à Pesquisa do Estado de São Paulo (FAPESP) for awarding financial aid to MAAP for the Uçá Project (Cases \# 1998/06055-0 and \# 2002/05614-2) and Conselho Nacional de Desenvolvimento Científico e Tecnológico (CNPq) for a scientific productivity grant to MAAP (Case \# 302813/2010-1). The authors are also grateful to the members of the Grupo de Pesquisa em Biologia de Crustáceos (CRUSTA), mainly to Gustavo Y. Hattori and Jelly M. Nakagaki for their help in the fieldworks, and to Gustavo H.S. Pinheiro for the elaboration of the map of the studied area.

\section{REFERENCES}

ALBERTS-HUBATSCH H, LEE SY, MEYNECKE JO, DIELE K, NORDHAUS I AND WOLFF M. 2016. Lifehistory, movement, and habitat use of Scylla serrata (Decapoda, Portunidae): current knowledge and future challenges. Hydrobiologia 763: 5-21.

ALCÂNTARA-FILHO P. 1978. Contribuição para o conhecimento da biologia e ecologia do caranguejo-uçá Ucides cordatus (Linnaeus, 1763) (Crustacea, Decapoda, Brachyura) no manguezal do Rio Ceará (Brasil). Arq Ciên Mar 18: 1-41.

ALVES RRN AND NISHIDA AK. 2003. Aspectos socioeconômicos e percepção ambiental dos catadores de caranguejo-uçá Ucides cordatus cordatus (L. 1763) 
(Decapoda, Brachyura) do estuário do Rio Mamanguape, nordeste do Brasil. Interciencia 28: 36-43.

ALVES RRN AND NISHIDA AK. 2004. Population structure of the mangrove crab Ucides cordatus (Crustacea: Decapoda: Brachyura) in the estuary of the Mamanguape River, Northeast Brazil. Trop Oceanogr 32: 23-37.

AMARAL ACZ AND JABLONSKI S. 2005. Conservação da biodiversidade marinha e costeira no Brasil. Megadiversidade 1: 43-51.

AMARAL KDS, VIEIRA IM, OSÓRIO FM, ROCHA JDM AND LIMA JF. 2014. Bioecology of the crab Ucides cordatus (Crustacea, Decapoda) in mangroves influenced by the Amazon River, Brazil. Acta Amaz 44: 213-222.

BLANDTT LS AND GLASER M. 2000. Sociedade humana e o recurso caranguejo (Ucides cordatus) na costa do Pará. In: Mangrove 2000, Sustainable use of estuaries and mangroves: Challenges and prospects Sustain. Recife. Anais..., Recife, p. 6.

BLANKENSTEYN A, CUNHA-FILHO D AND FREIRE AS. 1997. Distribuição, estoques pesqueiros e conteúdo protéico do caranguejo do mangue Ucides cordatus (L. 1763) (Brachyuram, Ocypodidae) nos manguezais da Baía das Laranjeiras e adjacências, Paraná, Brasil. Arq Biol Tecnol 40: 331-349.

BOEGER WA, PIE MR, OSTRENSKY A AND PATELLA L. 2005. Lethargic crab disease: Multidisciplinary evidence supports a mycotic etiology. Mem Inst Oswaldo Cruz 100: 161-167.

BRIGHT DB AND HOGUE CL. 1972. A synopsis of the burrowing land crabs of the world and list of their arthropod symbionts and burrow associates. Contrib Sci 220: 1-58.

CONTI RD AND NALESSO RC. 2010. Status of the population structure of the mangrove crab Ucides cordatus (Decapoda: Ocypodidae) on the Piraque-Acu River estuary, Espírito Santo, Brazil. Braz J Oceanogr 58: 81-92.

COSTA RS. 1979. Bioecologia do caranguejo-uçá, Ucides cordatus (Linnaeus, 1763) -Crustáceo, Decápode - no nordeste brasileiro. Bol Cear Agron 20: 1-74.

CUNHA-LIGNON M, COELHO C, ALMEIDA R, MENGHINI RP, SCHAEFFER-NOVELLI Y, CINTRÓN G AND DAHDOUH-GUEBAS F. 2011. Characterisation of mangrove forest types in view of conservation and management: a review of mangals at the Cananeia region, São Paulo State, Brazil. J Coast Res SI64: 349-353.

DIAS-NETO J. 2011. Proposta de Plano Nacional de Gestão para o Uso Sustentável do Caranguejo-Uçá, do Guaiamum e do Siri-Azul. Série Plano de Gestão dos Recursos 4, Brasília: IBAMA, 156 p.

DIELE K AND KOCH V. 2010. Growth and mortality of the exploited mangrove crab Ucides cordatus (Ucididae) in N-Brazil. J Exp Mar Bio Ecol 395: 171-180.

DIELE K, KOCH V AND SAINT-PAUL U. 2005. Population structure, catch composition and CPUE of the artisanally harvested mangrove crab Ucides cordatus (Ocypodidae) in the Caeté estuary, North Brazil: Indications for overfishing? Aquat Living Resour 18: 169-178.

DUARTE LF DE A, DURAN RS, MENDONÇA JT AND PINHEIRO MAA. 2014. Fishery of the uçá crab Ucides cordatus (Linnaeus, 1763) in a mangrove area in Cananéia, State of São Paulo, Brazil: Fishery performance, exploitation patterns and factors affecting the catches. Braz J Oceanogr 62: 187-199.

FAO. 2007. The world's mangroves 1980-2005, Rome: FAO Forestry Paper 153, $77 \mathrm{p}$.

FARIAS ID. 2009. Biologia populacional do caranguejo-uçá Ucides cordatus (Linnaeus, 1763) (Crustacea, Decapoda, Brachyura) no estuário do rio Maracaípe, Ipojuca, PE. Recife: Universidade Federal de Pernambuco, Tese de Mestrado, 44 p. (Unpublished).

FIRMO AMS, TOGNELLA MMP, CÓ WLO, BARBOZA RRD AND ALVES RRN. 2011. Perceptions of environmental changes and lethargic crab disease among crab harvesters in a Brazilian coastal community. J Ethnobiol Ethnomed 7: 34.

FISCARELLI AG AND PINHEIRO MAA. 2002. Perfil sócioeconômico e conhecimento etnobiológico do catador do caranguejo-uçá, Ucides cordatus (Linnaeus, 1763) nos manguezais de Iguape ( $24^{\circ} 41^{\prime}$ S), SP, Brasil. Actual Biol 24: $129-142$.

GLASER M AND DIELE K. 2004. Asymmetric outcomes: Assessing central aspects of the biological, economic and social sustainability of a mangrove crab fishery, Ucides cordatus (Ocypodidae), in North Brazil. Ecol Econ 49: 361-373.

GOES P, BRANCO JO, PINHEIRO MAA, BARBIERI E, COSTA D AND FERNANDES LL. 2010. Bioecology of the uçá-crab, Ucides cordatus (Linnaeus, 1763), in Vitória bay, Espírito Santo State, Brazil. Braz J Oceanogr 58: 153 163.

HATTORI GY. 2006. Densidade populacional do caranguejouçá, Ucides cordatus (Linnaeus, 1763) (Crustacea, Brachyura, Ocypodidade), na região de Iguape (SP). Jaboticabal: Universidade Estadual Paulista (UNESP) / FCAV, Tese de Doutorado, $146 \mathrm{p}$.

HERZ R. 1991. Os manguezais do Brasil. São Paulo: Instituto Oceanográfico / Universidade de São Paulo, 227 p.

IBAMA. 1994. Lagosta, Caranguejo-Uçá e Camarão-doNordeste. Brasília: Coleção Meio Ambiente. Série Estudos-Pesca 10, $190 \mathrm{p}$.

IBAMA. 2003a. Portaria n ${ }^{\circ}$ 34, de 24 de junho de 2003. Defeso pesqueiro do caranguejo-uçá (Ucides cordatus) nas regiões norte-nordeste do Brasil. DOU (25 de junho de 2003), Seção 1, p. 120.

IBAMA. 2003b. Portaria $n^{\circ}$ 52, de 30 de setembro de 2003. Defeso pesqueiro do caranguejo-uçá (Ucides cordatus) 
nas regiões sudeste-sul do Brasil. DOU ( 2 de outubro de 2003), Seção 1, p. 191.

JANKOWSKY M, PIRES JSR AND NORDI N. 2006. Contribuição ao manejo participativo do caranguejo-uçá, Ucides cordatus (L., 1763), em Cananéia - SP. Bol Inst Pesca, São Paulo 32: 221-228.

JENNERJAHN TC. 2012. Biogeochemical response of tropical coastal systems to present and past environmental change. Earth-Scie Rev 114: 19-41.

KENT CPS AND MCGUINNESS KA. 2006. A comparison of methods for estimating relative abundance of grapsid crabs. Wetl Ecol Manag 14: 1-9.

KOCH V. 1999. Epibenthic production and energy flow in the Caeté mangrove estuary, North Brazil. Bremen: Zentrum für Marine Tropenökologie (ZMT) 6, Doctoral Thesis, 97 p.

KOCH V AND WOLFF M. 2002. Energy budget and ecological role of mangrove epibenthos in the Caete estuary, North Brazil. Mar Ecol Prog Ser 228: 119-130.

KREBS CJ. 1999. Ecological Methodology, $2^{\text {nd }}$ ed., New York: Addison Wesley Longman, 620 p.

KRISTENSEN E. 2008. Mangrove crabs as ecosystem engineers; with emphasis on sediment processes. J Sea Res 59: 30-43.

LEGAT JFA, LEGAT AP, PEREIRA ALM, GÓES JM AND GÓES LCF. 2006. Caranguejo-uçá: métodos para captura, estocagem e transporte. Teresina: Embrapa Meio-Norte. Documentos 139, $25 \mathrm{p}$.

MACIA A, QUINCARDETE I AND PAULA J. 2001. A comparison of alternative techniques for estimating population density of the fiddler crab Uca annulipes at Saco mangrove, Inhaca Island (Mozambique). In: Paula J, Flores AAV and Fransen C (Eds), Advances in Crustacean Research, Proceedings of the $7^{\text {th }}$ Colloquium Crustacea Decapoda Mediterranea. Hydrobiology / Advances in Hydrobiology 449, The Netherlands: Kluwer Publishers, p. 213-219.

MACINTOSH DJ. 1988. The ecology and physiology of decapods of mangrove swamps. In: Fincham AA and Rainbow PS (Eds), Aspects of Decapod Crustacean Biology, Oxford: Oxford University Press, London, UK, p. 315-341.

MELO GAS. 1996. Manual de identificação dos Brachyura (caranguejos e siris) do litoral brasileiro, São Paulo: Editora Plêiade / FAPESP, 604 p.

MONTEIRO BR AND COELHO-FILHO PA. 2004. Estrutura populacional do caranguejo-uçá, Ucides cordatus (Linnaeus, 1763) (Crustacea, Decapoda, Ocypodidae), no estuário do Rio Paripe, Itamaracá-Pernambuco. Bol Tec Cient CEPENE 12: 99-111.

NASCIMENTO SA, SANTOS ER, BONFIM L AND COSTA RS. 1982. Estudo bio-ecológico do caranguejo-uçá Ucides cordatus. Sergipe: Admnistração Estadual do Meio Ambiente (ADEMA), 12 p.
NORDHAUS I AND WOLFF M. 2007. Feeding ecology of the mangrove crab Ucides cordatus (Ocypodidae): Food choice, food quality and assimilation efficiency. Mar Biol 151: 1665-1681.

NORDHAUS I, WOLFF M AND DIELE K. 2006. Litter processing and population food intake of the mangrove crab Ucides cordatus in a high intertidal forest in northern Brazil. Estuar Coast Shelf Sci 67: 239-250.

NORDI N, NISHIDA AK AND ALVES RRN. 2009. Effectiveness of two gathering techniques for Ucides cordatus in Northeast Brazil: Implications for the sustainability of mangrove ecosystems. Hum Ecol 37: 121-127.

PASSOS CA AND DI BENEDITTO APM. 2005. Captura comercial do caranguejo-uçá, Ucides cordatus (L., 1763), no Manguezal de Gargaú, RJ. Biotemas 18: 223-231.

PAULY D. 1983. Length-converted catch curves: a powerful tool for fisheries research in the tropics (Part I). Fishbyte 1: 9-13.

PAULY D. 1984a. Length-converted catch curves: a powerful tool for fisheries research in the tropics (Part II). Fishbyte 2: 17-19.

PAULY D. 1984b. Length-converted catch curves: a powerful tool for fisheries research in the tropics (Part III: Conclusion). Fishbyte 2: 9-10.

PÉREZ-CHI A. 2005. Densities, diel activity, burrow shape, and habitat characteristics of Gecarcinus (Johngarthia) planatus Stimpson, 1860 (Decapoda, Brachyura, Gecarcinidae) at Socorro Island, Revillagigedo, Mexico. Crustaceana 78: 255-272.

PINHEIRO MAA AND ALMEIDA R. 2015. Monitoramento da densidade e da estrutura populacional do caranguejouçá, Ucides cordatus (Linnaeus, 1763) (Brachyura: Ucididae). In: Turra A and Denadai MR (Eds), Protocolos para o Monitoramento de Habitats Bentônicos Costeiros, São Paulo: Instituto Oceanográfico da Universidade de São Paulo, São Paulo, Brasil, p. 122-133.

PINHEIRO MAA, DUARTE LF DE A, TOLEDO TR, ADAM ML AND TORRES RA. 2013. Habitat monitoring and genotoxicity in Ucides cordatus (Crustacea: Ucididae), as tools to manage a mangrove reserve in southeastern Brazil. Environ Monit Assess 185: 8273-8285.

PINHEIRO MAA AND FISCARELLI AG. 2001. Manual de apoio à fiscalização do caranguejo-uçá (Ucides cordatus). Itajaí: FCAV/UNESP Jaboticabal and CEPSUL/IBAMA, $43 \mathrm{p}$.

PINHEIRO MAA, FISCARELLI AG AND HATTORI GY. 2005. Growth of the mangrove crab Ucides cordatus (Brachyura, Ocypodidae). J Crustacean Biol 25: 293-301.

PINHEIRO MAA AND RODRIGUES AMT. 2011. Crustáceos sobre-explotados e plano nacional de gestão dos caranguejos uçá (Ucides cordatus), guaiamú (Cardisoma guanhumi) e do siri-azul (Callinectes sapidus): uma 
estratégia para evitar que passem ao status de ameaçados de extinção. Rev CEPSUL Biodiv Cons Mar 2: 50-57.

PINHEIRO MAA, SANTOS LCM, SOUZA CA, JOÃO MCA, DIAS-NETO J AND IVO CTC. 2016. Avaliação do caranguejo-uçá, Ucides cordatus (Linnaeus, 1763) (Decapoda: Ucididae). In: Pinheiro MAA and Boos H (Eds), Livro Vermelho dos Crustáceos do Brasil: Avaliação 2010-2014, Porto Alegre: Sociedade Brasileira de Carcinologia, Porto Alegre, Brasil, p. 441-458.

PIOU C, BERGER U AND FELLER IC. 2009. Spatial structure of a leaf-removing crab population in a mangrove of North-Brazil. Wetl Ecol Manag 17: 93-106.

POLIDORO BA ET AL. 2010. The loss of species: mangrove extinction risk and geographic areas of global concern. PLoS ONE 5: e10095.

QUINN GP AND KEOUGH MJ. 2002. Experimental design and data analysis for biologists. New York: Cambridge University Press, $537 \mathrm{p}$.

RICKER WE. 1975. Computation and interpretation of biological statistics of fish populations. Bulletin of Fisheries Research Board of Canada 191, Ottawa: Department of the Environment Fisheries and Marine Service, $382 \mathrm{p}$.

RODRIGUES AMT, BRANCO EJ, SACCARDO SA AND BLANKENSTEYN A. 2000. A explotação do caranguejo Ucides cordatus (Decapoda: Ocypodidae) e o processo de gestão participativa para normatização da atividade na região sudeste-sul do Brasil. Bol Inst Pesca 26: 63-78.

SAHER NU AND QURESHI NA. 2011. Density, distribution and population structure of Opusia indica (Ocypodoidae: Camptandriidae) in a coastal mangrove creek in Pakistan. Biologia 66: 138-145.

SANDRINI-NETO L AND LANA PC. 2012. Distribution patterns of the crab Ucides cordatus (Brachyura, Ucididae) at different spatial scales in subtropical mangroves of Paranaguá Bay (southern Brazil). Helgol Mar Res 66: 167174.

SANTOS CMH, PINHEIRO MAAAND HATTORI GY. 2009. Orientation and external morphology of burrows of the mangrove crab Ucides cordatus (Crustacea: Brachyura: Ucididae). J Mar Biol Assoc United Kingdom 89: 11171123.

SANTOS LCM, PINHEIRO MAA, DADOUH-GUEBAS F AND BITENCOURT M. 2016. Population status and fishery potential of the mangrove crab, Ucides cordatus (Linnaeus, 1763) in North-eastern Brazil. J Mar Biol Assoc United Kingdom 98: 299-309.

SCHMIDT AJ, DE OLIVEIRA MA, DE SOUZA EP, MAY M AND BRITO ASM. 2008. Relaçâo entre abertura de galeria e comprimento de cefalotórax do caranguejo-uçá, Ucides cordatus (Linnaeus, 1763) (Custacea-DecapodaBrachyura). Bol Tec Cient CEPENE 16: 51-58.

SKOV MW, VANNINI M, SHUNULA JP, HARTNOLL RG AND CANNICCI S. 2002. Quantifying the density of mangrove crabs: Ocypodidae and Grapsidae. Mar Biol 141: 725-732.

SOKAL RR AND ROHLF FJ. 1995. Biometry: the principles and practice of statistics in biological research. New York: W.H. Freeman, 776 p.

SOUTO FJB. 2007. Uma abordagem etnoecológica da pesca do caranguejo, Ucides cordatus, Linnaeus, 1763 (Decapoda: Brachyura), no manguezal do Distrito de Acupe (Santo Amaro-BA). Biotemas 20: 69-80.

SPALDING M, KAINUMA M AND COLLINS L. 2010. World Atlas of Mangroves. London: Earthscan Publishers Ltd., 319 p.

WAIHO K, MUSTAQIM M, FAZHAN H, WAN NORFAIZZA WI, MEGAT FH AND IKHWANUDDIN M. 2015. Mating behaviour of the orange mud crab, Scylla olivacea: The effect of sex ratio and stocking density on mating success. Aquac Reports 2: 50-57.

WARREN JH. 1990. The use of open burrows to estimate abundances of intertidal estuarine crabs. Aust J Ecol 15: 277-280.

WOLFF M, KOCH V AND ISAAC V. 2000. A trophic flow model of the Caeté mangrove estuary (North Brazil) with considerations for the sustainable use of its resources. Estuar Coast Shelf Sci 50: 789-803.

WUNDERLICH AC AND PINHEIRO MAA. 2013. Mangrove habitat partitioning by Ucides cordatus (Ucididae): Effects of the degree of tidal flooding and tree-species composition during its life cycle. Helgol Mar Res 67: 279-289.

WUNDERLICH AC, PINHEIRO MAA AND RODRIGUES AMT. 2008. Biologia do caranguejo-uçá, Ucides cordatus (Crustacea: Decapoda: Brachyura), na Baía da Babitonga, Santa Catarina, Brasil. Rev Bras Zool 25: 188-198. 